\title{
Role of CYP2EI genotypes in susceptibility to colorectal cancer in the Kashmiri population
}

\author{
A. Syed Sameer,' Saniya Nissar,' Qurteeba Qadri,' Shafia Alam,' Shahid Mudasir Baba' and Mushtaq A. Siddiqi ** \\ 'Department of Immunology and Molecular Medicine, Sher-I-Kashmir Institute of Medical Sciences, Soura, Srinagar, \\ Kashmir 190011, India \\ *Correspondence to: Tel: +91 194240 1013, Ext 2262; Fax: +91 194 2403470; E-mail: mousvi786@gmail.com/vc.tmuk@gmail.com
}

Date received (in revised form): 31st January 2011

\begin{abstract}
Cytochrome P450 2EI (CYP2EI) is a key enzyme involved in the metabolic activation of procarcinogens such as $\mathrm{N}$-nitrosoamines and low-molecular-weight organic compounds. The main aim of this study was to determine whether CYP450 2EI polymorphisms are associated with the risk of colorectal cancer (CRC). We investigated the genotype distribution of the CYP2EI gene Rsal and a 96-base pair (bp) insertion in 86 CRC cases in comparison with 160 healthy subjects. We found the frequency of the CYP2EI Rsal genotype to be 53.5 per cent (46/86) for $\mathrm{cl} / \mathrm{cl}, 17.4$ per cent (I5/86) for $\mathrm{cl} / \mathrm{c} 2$ and 29.I per cent (25/86) for c2/c2, and the CYP2EI 98-bp insertion frequencies to be 63.9 per cent $(55 / 86)$ for non-insertion (i/i), 22.I per cent (19/86) for heterozygous insertion (i/l) and 36.0 per cent (I2/86) for homozygous insertion (I/I) among CRC cases. We also found the CYP2EI Rsal c2/c2 and CYP2EI 98-bp heterozygous $\mathrm{i} / \mathrm{l}$ genotypes to be significantly associated with an increased risk of CRC $(p=0.0 \mathrm{I})$. We suggest that CYP2EI polymorphisms are involved in the susceptibility to developing CRC in the ethnic Kashmiri population.
\end{abstract}

Keywords: colorectal cancer, CYP2E, polymorphism, Kashmir

\section{Introduction}

Colorectal cancer (CRC) is one of the major causes of mortality and morbidity, and is the fourth most common cancer in men and the third most common cancer in women worldwide. ${ }^{1}$ Kashmir has been reported as being a high-incidence area for gastrointestinal (GIT) cancers. $^{2,3}$ In the Kashmir valley, CRC represents the third most common GIT cancer after oesophageal and gastric cancers. ${ }^{4-6}$

Epidemiological studies on various populations have shown that an increased risk of developing GIT cancers is associated with diet. ${ }^{2,7,8}$ One important hypothesis that has received a large amount of attention is that $\mathrm{N}$-nitroso compounds from dietary sources are involved in the carcinogenesis of GIT cancer. ${ }^{9,10}$ It is known that most exogenous (xenobiotics) and endogenous chemical carcinogens require biotransformation to activated forms to be carcinogenic. ${ }^{11,12}$ Most of the enzymes involved in drug metabolism are genetically polymorphic, and these polymorphisms may affect enzyme activity or inducibility. ${ }^{13-15}$

The cytochrome $\mathrm{P} 450$ 2E1 gene (CYP2E1) is located on chromosome $10 \mathrm{q} 26.3$. It is 18,754 base pairs (bp) long, consists of nine exons and eight introns and encodes a 493-amino acid protein. CYP2E1 belongs to the cytochrome P450 superfamily. ${ }^{16}$ It is a natural ethanol-inducible enzyme and is 
of great interest because of its role in the metabolism and bioactivation of many low molecular weight compounds, including ethanol and acetone, drugs such as acetaminophen, isoniazid, chlorzoxazone and fluorinated anaesthetics and many procarcinogens such as benzene, $\mathrm{N}$-nitrosoamines, vinyl chloride and styrene. $^{17-20}$

CYP2E1 contains six restriction fragment length polymorphisms, of which the RsaI polymorphism (CYP2E1*5B; C-1054T substitution) and the 96-bp insertion in its $5^{\prime}$-flanking region have drawn much interest. ${ }^{16,20,21}$ The RsaI polymorphism has been shown to affect the transcriptional level of the gene. The variant type of this polymorphic site can enhance the transcription and increase the level of CYP2E1 enzymatic activity in vitro. ${ }^{22}$ The variant allele of the 96-bp insertion polymorphism has been shown to express greater transcriptional activity. ${ }^{23}$

We carried out a case-control study in our population to determine if these CYP2E1 polymorphisms are associated with an altered risk of developing CRC. We also investigated whether there was a link between the clinicopathological variables and the CYP2E1 genotype, and hence their role in CRC predisposition.

\section{Materials and methods}

\section{Study population}

This study included 86 CRC cases. All patients were recruited from the Department of General Surgery, Sher-I-Kashmir Institute of Medical Sciences, Kashmir. Blood samples were collected from 160 age- and sex-matched individuals with no signs of any cardiac disease, to serve as external controls. The mean age of both patient and control groups was 52 years (see Table 1 for details).

Data on all CRC patients were obtained from personal interviews with patients and/or their guardians, and their medical records. All patients and/or guardians were informed about the study and their willingness to participate was recorded on a predesigned questionnaire (available on request). The collection and use of blood samples (from patients and controls) for this study had been previously approved by the appropriate institutional ethics committee.
Table I. Frequency distribution analysis of selected demographic and risk factors in colorectal cancer cases and controls

\begin{tabular}{|lccc|}
\hline Variable & $\begin{array}{c}\text { Cases } \\
(n=86)\end{array}$ & $\begin{array}{c}\text { Controls } \\
(n=160)\end{array}$ & $p$ Value \\
\hline $\begin{array}{l}\text { Age group } \\
\leq 50\end{array}$ & $30(34.9 \%)$ & $56(35.0 \%)$ & 1 \\
$>50$ & $56(65.1 \%)$ & $104(65.0 \%)$ & \\
\hline $\begin{array}{l}\text { Gender } \\
\text { Female }\end{array}$ & $37(43.0 \%)$ & $72(45.0 \%)$ & 0.764177 \\
Male & $49(67.0 \%)$ & $88(55.0 \%)$ & \\
\hline $\begin{array}{l}\text { Dwelling } \\
\text { Rural }\end{array}$ & $59(68.6 \%)$ & $104(65.0 \%)$ & 0.565659 \\
Urban & $27(31.4 \%)$ & $56(35.0 \%)$ & \\
\hline $\begin{array}{l}\text { Smoking status } \\
\text { Never }\end{array}$ & $31(36.0 \%)$ & $75(46.8 \%)$ & 0.102256 \\
Ever & $55(64.0 \%)$ & $85(53.2 \%)$ & \\
\hline $\begin{array}{l}\text { Pesticide exposure } \\
\text { Never }\end{array}$ & $33(38.4 \%)$ & $75(46.8 \%)$ & 0.200325 \\
Ever & $53(61.6 \%)$ & $85(53.2 \%)$ & \\
\hline
\end{tabular}

\section{DNA extraction and polymerase chain reaction}

DNA extraction was performed using the ammonium precipitation method. Genotyping for the CYP2E1 RsaI and 96-bp insertion polymorphisms was determined by the method described by Morita et al. ${ }^{21}$ The oligonucleotide primers used for the amplification of the target regions are listed in Table 2. The polymerase chain reaction (PCR) was carried out in a final volume of $25 \mu \mathrm{l}$, containing $50 \mathrm{ng}$ genomic DNA template, $1 \times$ PCR buffer (Fermentas, Glen Burnie, MD), with $2 \mathrm{mM} \mathrm{MgCl}_{2}$, $0.4 \mu \mathrm{M}$ of each primer (GenScript, Piscataway, NJ), $50 \mu \mathrm{M}$ deoxynucleotide triphosphates (dNTPs) (Fermentas) and 0.5 U DNA polymerase (Fermentas). For PCR amplification, the standard programme was used as follows: one initial denaturation step at $94^{\circ} \mathrm{C}$ for 7 minutes, followed by 30 denaturation cycles of 30 seconds at $94^{\circ} \mathrm{C}, 45$ seconds of annealing at $\mathrm{X}^{\circ} \mathrm{C}$ (See Table 2) and 45 seconds of extension at $72^{\circ} \mathrm{C}$ for 35 cycles, followed by a final elongation cycle at $72^{\circ} \mathrm{C}$ for 7 minutes.

The PCR product of CYP2E1 RsaI was $413 \mathrm{bp}$ in length and was then digested with $2 \mathrm{U}$ RsaI in a reaction mixture of $20 \mu \mathrm{l}$ for 3 hours at $37^{\circ} \mathrm{C}$. 
Table 2. Primers for CYP2EI gene polymorphism

\begin{tabular}{lll} 
Target codon & \multicolumn{1}{c}{ Sequence } & Amplicon (bp) \\
$\begin{array}{l}\text { CYP2EI* 5B } \\
\text { Rsal }\end{array}$ & F5'-CCAGTCGAGTCTACATTGTCA-3' & 413 bp \\
\hline $\begin{array}{l}\text { CYP2EI } \\
\text { 96-bp insertion }\end{array}$ & F5'-GTGATGGAAGCCTGAAGAACA-3' & \\
\hline
\end{tabular}

$\mathrm{T}_{\mathrm{m}}$, melting temperature.

The digestion resulted in fragments of $352 \mathrm{bp}$ and $61 \mathrm{bp}$ for the $\mathrm{c} 1$ allele. The PCR product of the CYP2E1 96-bp insertion allele was $729 \mathrm{bp}$ in length and that of the non-insertion allele was $633 \mathrm{bp}$ in length.

DNA amplicons, as well as the digestion products, were electrophoresed through a 2-3 per cent agarose gel (Genie, Bangalore, India) for resolution. The genotypes of $>20$ per cent of the samples were reassessed in a double-blind manner by two independent researchers, to confirm the results. A positive control for each polymorphism was used for 50 per cent of the samples.

\section{Statistical analysis}

The observed frequencies of the above genotypes in patients with CRC were compared with controls using chi-square or Fisher exact tests when the expected frequencies were small. The chi-square test was used to verify whether the genotype distributions were in Hardy-Weinberg equilibrium. Statistical significance was set at $p \leq 0.05$. Statistical analyses were performed using PASW version 18 software.

\section{Results}

A total of 86 CRC cases and 160 control subjects were included in this study. The patients comprised 49 males and 37 females $(\mathrm{M} / \mathrm{F}$ ratio $=1.32)$ and the control subjects consisted of 88 males and 72 females $(\mathrm{M} / \mathrm{F}$ ratio $=1.2)$. The mean age in patient and control groups was 52 years. No significant gender- or age-related differences were observed between the groups $(p>0.05)$. Furthermore, of 86 confirmed cases of CRC, 81 were sporadic, four were familial adenomatous polyposis and one case was hereditary non-polyposis (Lynch Syndrome) CRC. All but one case had an adenocarcinoma, one had squamous cell carcinoma of the basal cell type. Thirty-six patients had carcinoma in the colon and 50 carcinoma in the rectum. Fifty-nine were ruraland 27 urban-living, and 55 were smokers and 31 non-smokers (see Table 1 for further details).

Among the CRC cases, we found the frequency of the CYP2E1 RsaI genotype to be 53.5 per cent (46/86) for $\mathrm{c} 1 / \mathrm{c} 1,17.4$ per cent $(15 / 86)$ for $\mathrm{c} 1 / \mathrm{c} 2$ and 29.1 per cent $(25 / 86)$ for $c 2 / c 2$, while the frequency in the general control population was 70.0 per cent $(112 / 160)$ for $\mathrm{c} 1 / \mathrm{c} 1,12.5$ per cent $(20 /$ 160) for $\mathrm{c} 1 / \mathrm{c} 2$ and 17.5 per cent $(28 / 160)$ for c2/c2. The association between the CYP2E1 RsaI polymorphism and the CRC cases was found to be significant $(p<0.05)$ (Table 3). Furthermore, for the 96-bp insertion polymorphism of CYP2E1, the genotype frequencies were 63.9 per cent (55/ 86) for non-insertion (i/i), 22.1 per cent (19/86) for the heterozygous insertion (i/I) and 13.9 per cent $(12 / 86)$ for the homozygous insertion (I/I), while in the general control population the frequency of i/i was found to be 81.3 per cent $(130 / 160), 7.5$ per cent $(12 / 160)$ for $\mathrm{i} / \mathrm{I}$ and 11.3 per cent (18/160) I/I. The association of the CYP2E1 98-bp insertion polymorphism with the CRC cases was also found to be significant $(p<0.05)$ (Table 3$)$. In individual patients it was found that the CYP2E1 RsaI c2/c2 and CYP2E1 96-bp heterozygous i/I genotypes were both associated with an increased risk of CRC ( $p=0.01$ and 0.0009 , respectively).

Analysis of the CYP2E1 RsaI and 98-bp insertion polymorphisms with that of the clinicopathological parameters also revealed significant associations with many parameters (Tables 4 and 5). The CYP2E1 RsaI c2/c2 genotype was associated 
Table 3. Genotype frequencies of CYP2EI polymorphism in cases and controls

\begin{tabular}{|c|c|c|c|c|}
\hline CYP2EI genotype & $\begin{array}{c}\text { Cases } \\
(n=86)\end{array}$ & $\begin{array}{l}\text { Controls } \\
(n=160)\end{array}$ & OR $(95 \% \mathrm{CI}) ; \chi^{2 a} ; p$ value ${ }^{b}$ & $\begin{array}{c}\chi^{2} ; p \text { value } \\
\text { (overall) }\end{array}$ \\
\hline \multicolumn{5}{|l|}{ Rsal } \\
\hline cl/cl (wild-type) & $46(53.5 \%)$ & I I 2 (70.0\%) & $\mathrm{I} .0$ (ref) & $6.8 I ; 0.03$ \\
\hline $\mathrm{cl} / \mathrm{c} 2$ & $15(17.4 \%)$ & $20(12.5 \%)$ & 1.8 (0.86-3.87); $0.11 ; 0.15$ & \\
\hline c2/c2 (variant) & $25(29.1 \%)$ & $28(17.5 \%)$ & 2.17 (1.14-4.1I); $0.01 ; 0.01$ & \\
\hline $\mathrm{cl} / \mathrm{c} 2$ or $\mathrm{c} 2 / \mathrm{c} 2$ & $40(46.5 \%)$ & $48(30.0 \%)$ & 2.02 (1.17-3.48); 0.009; 0.01 & \\
\hline \multicolumn{5}{|l|}{ 96-bp insertion } \\
\hline i/i (non-insertion) & 55 (63.9\%) & 130 (8I.3\%) & $\mathrm{I} .0$ (ref) & 12.1; 0.002 \\
\hline $\mathrm{i} / \mathrm{l}$ & $19(22.1 \%)$ & $12(7.5 \%)$ & 3.74 (1.7-8.23); 0.0006; 0.0009 & \\
\hline I/I (insertion) & $12(13.9 \%)$ & $18(11.3 \%)$ & 1.57 (0.79-3.49); 0.25; 0.29 & \\
\hline $\mathrm{i} / \mathrm{I}$ or $\mathrm{I} / \mathrm{I}$ & $31(36.0 \%)$ & $30(18.8 \%)$ & 2.44 (I.3I-4.4I);0.003; 0.003 & \\
\hline
\end{tabular}

${ }^{\text {a }}$ Pearson value; ${ }^{\text {b }}$ isher exact value. Significant $p$ values are shown in bold.

significantly $(p<0.05)$ with age, nodal status (Table 4) and tumour grade, and the CYP2E1 96-bp i/I genotype was associated significantly $(p<0.05)$ with tumour location (Table 5).

\section{Discussion}

As reported previously in various studies on the Kashmiri population, ${ }^{2,4,5}$ it has been proven beyond doubt that this population is exposed to a special set of environmental and dietary risks, including exposure to nitroso compounds, amines and nitrates, reported to be present in local foodstuffs, most of which have been shown to contain important irritants and carcinogens. ${ }^{3,6}$

In the present study, we assessed the two most common single nucleotide polymorphisms of CYP2E1, RsaI and the 96-bp insertion, in an ethnic Kashmiri population for the first time, as the role of these polymorphisms in relation to the risk of CRC has not been reported from this part of the world.

Although a number of studies have been carried out around the world on the association between the CYP2E1 polymorphism and cancer risk, the findings have been inconsistent. ${ }^{24}$ Some studies demonstrated that the common genotype or alleles (i.e. RsaI and the 96-bp insertion) confer a greater risk of oral and pharyngeal, ${ }^{25}$ oesophageal, ${ }^{26}$ liver $^{27}$ and lung ${ }^{28}$ cancers. In other studies, however, an increased risk of oral, ${ }^{29}$ nasopharyngeal, ${ }^{30}$ liver $^{31}$ and colorectal ${ }^{32,33}$ cancers was observed with the rare genotype or allele carriers (i.e. the variant form of these two genotypes).

In the present study, we found the frequency of the CYP2E1 RsaI genotype to be 53.5 per cent (46/86) for c1/c1, 17.4 per cent $(15 / 86)$ for c1/c2 and 29.1 per cent $(25 / 86)$ for $\mathrm{c} 2 / \mathrm{c} 2$ among CRC cases, and the CYP2E1 RsaI polymorphism to be significantly associated with the risk of CRC $(p<$ 0.05). The overall risk of CRC was found to be 2.17 times higher in case of $\mathrm{c} 2 / \mathrm{c} 2$ homozygous state. These results were consistent with those of Kiss et al. ${ }^{32}$ and $\mathrm{Yu}$ et al. ${ }^{33}$ Kiss et al. found the CYP2E1 c2 allele to be significantly associated with CRC (odds ratio 1.91, 95 per cent confidence interval 1.05-3.52) in a Hungarian population. ${ }^{32}$ Yu et al. found the CYP2E1 c2 allele to be a susceptibility factor for CRC. ${ }^{33}$ This may be because of the increased transcriptional activation of the $c 2$ variant of the CYP2E1 gene, with elevated expression levels of CYP2E1 mRNA and protein. ${ }^{34}$ We also found a significant association between the CYP2E1 RsaI genotype and age $(>50)$, nodal status (involved) and tumour grade $(C+D)$. Furthermore, a recent meta-analysis by Zhou et al. also revealed the CYP2EI RsaI c2/c2 genotype to be associated with an increased risk of CRC. ${ }^{20}$

In the case of the 98-bp insertion polymorphism, we found that the genotype frequencies were 63.9 per cent $(55 / 86)$ for non-insertion (i/i), 22.1 
Table 4. Association between CYP2EI (Rsal) polymorphism and clinicopathological characteristics

\begin{tabular}{|c|c|c|c|c|c|}
\hline \multirow[t]{2}{*}{ Variables } & \multicolumn{5}{|c|}{ Cases $(n=86)$} \\
\hline & $n=86$ & $\begin{array}{c}\mathrm{cl} / \mathrm{cl} \\
46(53.5 \%)\end{array}$ & $\begin{array}{c}c \mid / c 2 \\
15(17.4 \%)\end{array}$ & $\begin{array}{c}c 2 / c 2 \\
25(29.1 \%)\end{array}$ & $\chi^{2} ; p$ value \\
\hline \multicolumn{6}{|l|}{ Age group } \\
\hline$\leq 50$ & 30 (34.9\%) & 21 & 5 & 4 & $6.29 ; 0.04$ \\
\hline$>50$ & $56(65.1 \%)$ & 25 & 10 & 21 & \\
\hline \multicolumn{6}{|l|}{ Gender } \\
\hline Female & $37(43.0 \%)$ & 20 & 6 & 11 & $0.07 ; 0.96$ \\
\hline Male & 49 (67.0\%) & 26 & 9 & 14 & \\
\hline \multicolumn{6}{|l|}{ Dwelling } \\
\hline Rural & $59(68.6 \%)$ & 27 & II & 21 & $5.0 ; 0.08$ \\
\hline Urban & $27(31.4 \%)$ & 19 & 4 & 4 & \\
\hline \multicolumn{6}{|c|}{ Smoking status } \\
\hline Ever & 55 (64.0\%) & 29 & 8 & 18 & $\mathrm{I} .45 ; 0.48$ \\
\hline Never & 31 (36.0\%) & 17 & 7 & 7 & \\
\hline \multicolumn{6}{|c|}{ Tumour location } \\
\hline Colon & $36(41.9 \%)$ & 19 & 5 & 12 & $0.84 ; 0.65$ \\
\hline Rectum & $50(58.1 \%)$ & 27 & 10 & 13 & \\
\hline \multicolumn{6}{|l|}{ Nodal status } \\
\hline Involved & $48(55.8 \%)$ & 24 & 4 & 20 & II.34; 0.003 \\
\hline Not Involved & 38 (44.2\%) & 22 & 11 & 5 & \\
\hline \multicolumn{6}{|l|}{ Tumour grade } \\
\hline$A+B$ & $38(44.2 \%)$ & 22 & 11 & 5 & II.34; 0.003 \\
\hline$C+D$ & $48(55.8 \%)$ & 24 & 4 & 20 & \\
\hline \multicolumn{6}{|c|}{ Pesticide exposure } \\
\hline Ever & $53(61.6 \%)$ & 26 & 8 & 19 & $3.13 ; 0.20$ \\
\hline Never & $33(38.4 \%)$ & 20 & 7 & 6 & \\
\hline \multicolumn{6}{|c|}{ Bleeding PR/constipation } \\
\hline Yes & $60(69.8 \%)$ & 32 & 10 & 18 & $0.13 ; 0.93$ \\
\hline No & $26(30.2 \%)$ & 14 & 5 & 7 & \\
\hline \multicolumn{6}{|l|}{ Tumour type ${ }^{a}$} \\
\hline Mucinous & $33(38.5 \%)$ & 20 & 6 & 7 & I.84; 0.39 \\
\hline Non-mucinous & $52(60.5 \%)$ & 25 & 9 & 18 & \\
\hline
\end{tabular}

${ }^{a}$ One was squamous cell carcinoma. Significant $p$ values are shown in bold.

per cent (19/86) for heterozygous (i/I) and 36.0 per cent $(12 / 86)$ in case of homozygous insertion (I/I) among CRC (86) cases and heterozygous i/I genotype to be associated with increased risk of CRC $(p=0.0009)$. The overall risk of CRC was found to be 3.74 times higher in the case of the $\mathrm{i} / \mathrm{I}$ heterozygous state. These results are different from those found in a previous study on $\mathrm{CRC} ;{ }^{21}$ however, the present study is only the third such study on this polymorphism to have been carried out. The other study in this field examined the relationship between the 96-bp insertion polymorphism and cancer risk, and was carried out in Japan by Itoga et al., ${ }^{35}$ who found an increased risk of oesophageal cancer, but not of lung cancer, in individuals who had two variant 96-bp insertion alleles.

We also found a significant association between the CYP2E1 i/I heterozygous genotype and the 
Table 5. Association between CYP2EI (96 bp) polymorphism and clinicopathological characteristics

\begin{tabular}{|c|c|c|c|c|c|}
\hline \multirow[t]{2}{*}{ Variables } & \multicolumn{5}{|c|}{ Cases $(n=86)$} \\
\hline & $n=86$ & i/i 55 (63.9\%) & i/l 19 (22.1\%) & I/I I 2 (I3.9\%) & $\chi^{2} ; p$ value \\
\hline \multicolumn{6}{|l|}{ Age group } \\
\hline$\leq 50$ & 30 (34.9\%) & 19 & 7 & 4 & $0.05 ; 0.97$ \\
\hline$>50$ & $56(65.1 \%)$ & 36 & 12 & 8 & \\
\hline \multicolumn{6}{|l|}{ Gender } \\
\hline Female & 37 (43.0\%) & 26 & 8 & 3 & $2.0 ; 0.36$ \\
\hline Male & 49 (67.0\%) & 29 & II & 9 & \\
\hline \multicolumn{6}{|l|}{ Dwelling } \\
\hline Rural & 59 (68.6\%) & 38 & 13 & 8 & $0.03 ; 0.98$ \\
\hline Urban & 27 (3I.4\%) & 17 & 6 & 4 & \\
\hline \multicolumn{6}{|c|}{ Smoking status } \\
\hline Ever & 55 (64.0\%) & 35 & 10 & 10 & $3.01 ; 0.22$ \\
\hline Never & $31(36.0 \%)$ & 20 & 9 & 2 & \\
\hline \multicolumn{6}{|c|}{ Tumour location } \\
\hline Colon & 36 (4I.9\%) & 22 & 5 & 9 & $7.38 ; 0.02$ \\
\hline Rectum & $50(58.1 \%)$ & 33 & 14 & 3 & \\
\hline \multicolumn{6}{|l|}{ Nodal status } \\
\hline Involved & 48 (55.8\%) & 28 & 12 & 8 & $1.53 ; 0.46$ \\
\hline Not Involved & 38 (44.2\%) & 27 & 7 & 4 & \\
\hline \multicolumn{6}{|l|}{ Tumour grade } \\
\hline$A+B$ & 38 (44.2\%) & 27 & 7 & 4 & $1.53 ; 0.46$ \\
\hline$C+D$ & 48 (55.8\%) & 28 & 12 & 8 & \\
\hline \multicolumn{6}{|c|}{ Pesticide exposure } \\
\hline Ever & $53(61.6 \%)$ & 38 & 9 & 6 & $3.62 ; 0.16$ \\
\hline Never & $33(38.4 \%)$ & 17 & 10 & 6 & \\
\hline \multicolumn{6}{|c|}{ Bleeding PR/constipation } \\
\hline Yes & $60(69.8 \%)$ & 42 & II & 7 & $3.15 ; 0.20$ \\
\hline No & $26(30.2 \%)$ & 13 & 8 & 5 & \\
\hline \multicolumn{6}{|l|}{ Tumour type* } \\
\hline Mucinous & $33(38.5 \%)$ & 22 & 7 & 4 & $0.27 ; 0.87$ \\
\hline Non-mucinous & $52(60.5 \%)$ & 32 & 12 & 8 & \\
\hline
\end{tabular}

*One was squamous cell carcinoma. Significant $p$ values are shown in bold.

tumour location (rectum). This finding was in line with that of a case-control study carried out in Hawaii, where the authors showed an increased risk of CRC, especially of rectal cancer, in those having at least one 96-bp insertion. ${ }^{36}$ This was hypothesised to be because of a high intake of red meat, which increases the endogenous production of $\mathrm{N}$-nitroso compounds in the intestine. The Kashmiri population is also known to consume high quantities of red meat.
Furthermore, it has been found that both the RsaI c2 and 96-bp I alleles are fairly common in Asian populations compared with Caucasians. In the present study, we found the frequencies of RsaI c2 and 96-bp I alleles to be of 30.0 per cent and 18.8 per cent, respectively (see Table 3 ). These frequencies are similar to those found for these alleles in other Asian populations. The frequencies of the RsaI c2 allele were 22 per cent in Japanese, ${ }^{21} 4$ per cent in Caucasians ${ }^{36}$ and 15 per cent in Hawaiians. ${ }^{36}$ 
The frequencies of the 96-bp insertion allele were 23 per cent in Japanese, ${ }^{21} 15$ per cent in Taiwanese, ${ }^{37}$ 10 per cent in African-American, ${ }^{37}$ and 2 per cent in Caucasian ${ }^{37}$ subjects.

\section{Conclusion}

We conclude that there is a significant relationship between the CYP2E1 RsaI and 96-bp insertion polymorphisms and the risk of CRC in the ethnic Kashmiri population. We also observed a significant correlation between the RsaI c2/c2 variant and 96-bp i/I heterozygous genotype with various clinicopathological variables in this population. These correlations now need to be authenticated in a large sample study, in order to discern racial differences and determine the aggressiveness of CRC.

\section{Acknowledgments}

The authors gratefully acknowledge the financial support provided by the Sher-I-Kashmir Institute of Medical Sciences, Kashmir, for this work. We also thank the head and technical staff of the operating theatre in the Department of General Surgery at the Institute who helped us with tissue procurement, and the anonymous pathologists at the Department of Pathology also at the Sher-I-Kashmir Institute of Medical Sciences for the histopathological assessment of the tumour tissues.

\section{References}

1. Center, M.M., Jemal, A. and Ward, E. (2009), 'International trends in colorectal cancer incidence rates', Cancer Epidemiol. Biomarkers Prev. Vol. 18, pp. $1688-1694$

2. Mir, M.M., Dar, N.A., Gochhait, S., Zargar, S.A. et al. (2005), 'p53 mutation profile of squamous cell carcinomas of the esophagus in Kashmir (India): A high-incidence area', Int. J. Cancer Vol. 116, pp. $62-68$.

3. Murtaza, I., Mushtaq, D., Margoob, M.A., Dutt, A. et al. (2006), 'A study on p53 gene alterations in esophageal squamous cell carcinoma and their correlation to common dietary risk factors among population of the Kashmir valley', World J. Gastroenterol. Vol. 12, pp. 4033-4037.

4. Sameer, A.S., Rehman, S., Pandith, A.A., Syeed, N. et al. (2009), 'Molecular gate keepers succumb to gene aberrations in colorectal cancer in Kashmiri population, revealing a high incidence area', Saudi J. Gastroenterol. Vol. 15, pp. 244-252.

5. Sameer, A.S., Chowdri, N.A., Syeed, N., Banday, M. et al. (2010), 'SMAD4 - Molecular gladiator of the TGF-beta signaling is trampled upon by mutational insufficiency in colorectal carcinoma of Kashmiri population: An analysis with relation to KRAS proto-oncogene', $B M C$ Cancer Vol. 10, p. 300.

6. Siddiqi, M., Kumar, R., Fazili, Z., Spiegelhalder, B. et al. (1992), 'Increased exposure to dietary amines and nitrate in a population at high risk of esophageal and gastric cancer in Kashmir (India)', Carcinogenesis Vol. 13, pp. 1331-1335.
7. Ji, B.T., Chow, W.H., Yang, G., Mclaughlin, J.K. et al. (1998), 'Dietary habits and stomach cancer in Shanghai, China', Int. J. Cancer Vol. 76, pp. 659-664.

8. Hill, M.H. (1998), 'Nutritional and metabolic aspects of gastrointestinal cancer', Curr. Opin. Clin. Nutr. Metab. Care Vol. 1, pp. 405-407.

9. Deng, D.J., Chang, Y. and Li, J. (1997), 'Comparison of total Nnitrosamides in fasting gastric juice from subjects in high and low risk areas for gastric cancer', Zhonghua Zhong Liu Za Zhi, vol. 19, pp. 96-99.

10. Ward, M.H. and Lopez-Carrillo, L. (1999), 'Dietary factors and the risk of gastric cancer in Mexico City', Am. J. Epidemiol. Vol. 149, pp. $925-932$.

11. Kim, J.W., Lee, C.G., Park, Y.G., Kim, K.S. et al. (2000), 'Combined analysis of germline polymorphisms of P53, GSTM1, GSTT1, CYP1A1, and CYP2E1', Cancer Vol. 88, pp. 2082-2091.

12. Slattery, M.L., Edwards, S.L., Samowitz, W. and Potter, J. (2000), 'Associations between family history of cancer and genes coding for metabolizing enzymes (United States)', Cancer Causes Control Vol. 11, pp. 799-803.

13. Gonzalez, FJ. and Kimura, S. (2001), 'Understanding the role of xenobiotic metabolism in chemical carcinogenesis using gene knockout mice', Mutat Res. Vol. 477, pp. 79-87.

14. Chhabra, S.K., Reed, C.D., Anderson, L.M. and Shiao, Y.H. (2001), 'Comparison of the polymorphic regions of the cytochrome P450 CYP2E1 gene of humans and patas and cynomolgus monkeys', Carcinogenesis Vol. 20, pp. 1031-1034.

15. Reid, J.M., Kuffel, M.J., Miller, J.K., Rios, R. et al. (1999), 'Metabolic activation of dacarbazine by human cytochromes P450: The role of CYP1A1, CYP1A2, and CYP2E1', Clin. Cancer Res. Vol. 5, pp. 2192-2197.

16. Wang, Y., Yang, H., Li, L., Wang, H. et al. (2010), 'Association between CYP2E1 genetic polymorphisms and lung cancer risk: A meta-analysis', Eur. J. Cancer Vol. 46, pp. 758-764.

17. Guengerich, F.P., Kim, D.H. and Iwasaki, M. (1991), 'Role of human cytochrome P450 IIE1 in the oxidation of many low molecular weight cancer suspects', Chem. Res. Toxicol. Vol. 4, pp. 168-179.

18. Kharasch, E.D. and Thummel, K.E. (1993), 'Identification of cytochrome P450 2E1 as the predominant enzyme catalyzing human liver microsomal defluorination of sevoflurane, isoflurane, and methoxyflurane', Anesthesiology Vol. 79, pp. 795-807.

19. Ulusoy, G., Arinç, E. and Adali, O. (2007), 'Genotype and allele frequencies of polymorphic CYP2E1 in the Turkish population', Arch. Toxicol. Vol. 81, pp. 711-718.

20. Zhou, G.W., Hu, J. and Li, Q. (2010), 'CYP2E1 Pst/Rsa polymorphism and colorectal cancer risk: A meta-analysis', World J. Gastroenterol. Vol. 16, pp. 2949-2953.

21. Morita, M., Tabata, S., Tajima, O., Yin, G. et al. (2008), 'Genetic polymorphisms of CYP2E1 and risk of colorectal adenomas in the Self Defense Forces Health Study', Cancer Epidemiol. Biomarkers Prev. Vol. 17, pp. $1800-1807$.

22. Hayashi, S., Watanabe, J. and Kawajiri, K. (1991), 'Genetic polymorphisms in the $5^{\prime}$-flanking region change transcriptional regulation of the human cytochrome P450IIE1 gene', J. Biochem. Vol. 110, pp. 559-565.

23. Nomura, F, Itoga, S., Uchimoto, T., Tomonaga, T. et al. (2003), 'Transcriptional activity of the tandem repeat polymorphism in the $5^{\prime}$-flanking region of the human CYP2E1 gene'. Alcohol Clin. Exp. Res. Vol. 27, pp. 42S-46S

24. Gao, C.M., Takezaki, T., Wu, J.Z., Chen, M.B. et al. (2007), 'CYP2E1 RsaI polymorphism impacts on risk of colorectal cancer association with smoking and alcohol drinking', World J. Gastroenterol. Vol. 13, pp. $5725-5730$.

25. Bouchardy, C., Hirvonen, A., Coutelle, C., Ward, P.J. et al. (2000), 'Role of alcohol dehydrogenase 3 and cytochrome P-4502E1 genotypes in susceptibility to cancers of the upper aerodigestive tract', Int. J. Cancer. Vol. 87, pp. 734-740

26. Tan, W., Song, N., Wang, G.Q., Liu, Q. et al. (2000), 'Impact of genetic polymorphisms in cytochrome P450 2E1 and glutathione S-transferases M1, T1, and P1 on susceptibility to esophageal cancer among high-risk 
individuals in China', Cancer Epidemiol. Biomarkers Prev. Vol. 9. pp. 551-556.

27. Yu, M.W., Gladek-Yarborough, A., Chiamprasert, S., Santella, R.M. et al. (1995), "Cytochrome P450 2E1 and glutathione S-transferase M1 polymorphisms and susceptibility to hepatocellular carcinoma', Gastroenterology Vol. 109, pp. 1266-1273.

28. Le Marchand, L., Sivaraman, L., Pierce, L., Seifried, A. et al. (1998), 'Associations of CYP1A1, GSTM1, and CYP2E1 polymorphisms with lung cancer suggest cell type specificities to tobacco carcinogens', Cancer Res. Vol. 58, pp. $4858-4863$.

29. Hung, H.C., Chuang, J., Chien, Y.C., Chern, H.D. et al. (1997), 'Genetic polymorphisms of CYP2E1, GSTM1, and GSTT1: Environmental factors and risk of oral cancer', Cancer Epidemiol. Biomarkers Prev. Vol. 6, pp. 901-905.

30. Hildesheim, A., Anderson, L.M., Chen, C.J., Cheng, Y.J. et al. (1997), 'CYP2E1 genetic polymorphisms and risk of nasopharyngeal carcinoma in Taiwan', J. Natl. Cancer Inst. Vol. 89, pp. 1207-1212.

31. Ladero, J.M., Agundez, J.A., Rodriguez-Lescure, A., Diaz-Rubio, M. et al. (1996), 'RsaI polymorphism at the cytochrome P4502E1 locus and risk of hepatocellular carcinoma', Gut Vol. 39, pp. 330-333.
32. Kiss, I., Sandor, J., Pajkos, G., Bogner, B. et al. (2000), 'Colorectal cancer risk in relation to genetic polymorphism of cytochrome $\mathrm{P} 450$ 1A1, 2E1, and glutathione-S-transferase M1 enzymes', Anticancer Res. Vol. 20, pp. 519-522.

33. Yu, W.P., Chen, K., Ma, X.Y., Yao, K.Y. et al. (2004), ‘Genetic polymorphism in cytochrome P450 2E1, salted food and colorectal cancer susceptibility: A case-control study', Zhonghua Yufang Yixue Zazhi Vol. 38, pp. 162-166.

34. Carriere, V., Berthou, F., Baird, S., Belloc, C. et al. (1996), 'Human cytochrome P450 2E1 (CYP2E1): From genotype to phenotype', Pharmacogenetics Vol. 6, pp. 203-211.

35. Itoga, S., Nomura, F, Makino, Y., Tomonaga, T. et al. (2002), 'Tandem repeat polymorphism of the CYP2E1 gene: An association study with esophageal cancer and lung cancer', Alcohol Clin. Exp. Res. Vol. 26, pp. 15S-19S.

36. Le Marchand, L., Donlon, T., Seifried, A. and Wilkens, L.R. (2002), 'Red meat intake, CYP2E1 genetic polymorphisms, and colorectal cancer risk', Cancer Epidemiol. Biomarkers Prev. Vol. 11, pp. 1019-1024.

37. Fritsche, E., Pittman, G.S. and Bell, D.A. (2000), 'Localization, sequence analysis, and ethnic distribution of a 96-bp insertion in the promoter of the human CYP2E1 gene', Mutat. Res. Vol. 432, pp. 1-5. 